\title{
FACTORS AFFECTING THE LEVEL OF FIRM'S ABILITY TO CREATE VALUE RELATIVE TO CAPITAL INVESTED AND FINANCIAL DISTRESS PROBABILITY
}

\author{
Khaira Amalia FACHRUDIN ${ }^{1 *}$
}

\begin{abstract}
Received: September 2021 | Accepted: November 2021 | Published: December 2021
Please cite this paper as: Fachrudin, K.A. (2021) Factors affecting level of company's ability to create value relative to capital invested and probability of financial distress, Holistica Journal of Business and Public Administration, Vol. 12, Iss. 3, pp.101-114
\end{abstract}

\begin{abstract}
The level of firms's ability to create value relative to invested capital (LACVIC) is proxied by Price to Book Value Ratio. Price to Book Ratio is also a proxy of firm value. The purpose of this study was to examine the effect of growth, profitability, size and assets tangibility on the level of firm's ability to create value with probability of financial distress as an intervening variable. This study was conducted on public companies in Indonesia during the periods of 2013 - 2017. The panel data were analyzed by using Partial Least Square. Results indicate that assets tangibility has positive and significant effect on financial distress probability. Financial distress probability has no significant effect on LACVIC. Profitability, firm size, and assets tangibility have significant effects LACVIC directly, but they have no significant effect on it trough financial distress probability. It is indicating that financial distress probability does not act as an intervening variable. The implication is that companies should not have much assets tangibility because it can increase financial distress probability and decrease LACVIC

Keywords: company's health level; financial distress probability; the level of firms's ability to create value relative to invested capital; tangibility.
\end{abstract}

\section{Introduction}

Stock valuation is an aspect of investment decision making. Stock valuation with relative valuation method using equity valuation multiples. One of the specific value driver in equity valuation multiples is price to book value. Price-book value indicates LACVIC and

1 Faculty of Economic and Business, Universitas Sumatera Utara, Medan, Indonesia, khaira@usu.ac.id

* Corresponding author 
indicates how much investors are willing to pay to company's book value (E. F. Brigham \& Daves, 2013).

Price - book value or market to book value is often used as a proxy for firm value (Chen, Cheng, \& Hwang, 2005); (Purwohandoko, 2017); and (Aggarwal \& Padhan, 2017) . Market value ratios give management an indication of what investors think of the company's past performance and future prospects. This is because stock market prices are formed by investor perceptions of company fundamentals, economic situation, and investor expectations. Based on the opinions of these researchers, the Price to Book Value in this study is not only a proxy of LACVIC but also as a proxy for firm value.

Financial distress probability is the probability of financial difficulties in the future. Financial distress has several types, namely failure - which includes both economic and business; insolvency - which includes both technical insolvency and bankruptcy; and legal bankruptcy (Fachrudin, 2008) found a formula to predict financial distress probability of manufacturing companies in Indonesia that are insolvency in bankruptcy. The distress criteria in Fachrudin's research are companies that have negative net income for 3 years or more, experience a debt failure (default) and conduct debt restructuring, total assets is smaller than total liability for 3 years or more and / or delisted by the Jakarta Stock Exchange due to financial difficulties.

The formula are :

$$
P_{\text {it }}=1 /\left[1+2,71828^{-(-5,472+9,555 \times 1 i t-32,347 \times 2 \text { it })}\right]
$$

Where $X_{1}$ is the ratio of total liabilities to total assets; and $X_{2}$ is the ratio of net income to total assets. This model has $93.1 \%$ accuracy in predicting the occurrence of financial distress in the coming year and accuracy of $86.2 \%$ to predict financial distress that will occur in the next 2 years. This probability lies between the numbers 0 and 1 . Number 0 indicates the company's health is very good and number 1 indicates the company's financial difficulties are in severe condition. This number between 0 and 1 also shows a company's health level.

One of the causes of financial difficulties is company's capital structure dominated by debt. Capital structure is a mix of debt and equity used for financing (Fachrudin, 2011). The greater the financing of debt, and the greater the fixed interest expense, the greater the probability of decreasing earnings which will lead to financial difficulties, therefore the higher the financial distress probability.

Modigliani and Miller Model said that the use of debt has a significant relationship with firm value. The trade off model said that the use of debt will increase the value of the company until a certain point, then an increase in debt will decrease the value of the company because the increase in benefits of using debt is not balanced with increase in cost of financial difficulties and agency problems. If the cost of financial distress and agency cost are considered, so a large debt will increase the fixed burden of interest costs and the greater the probability that the company will experience financial distress. 
HOLISTICA Vol 12, Issue 3, 2021, pp. 101-114

(Fachrudin, 2008) said that financial distress can have a negative impact on company value.

Companies that experience financial distress always experience negative profits so that their ability to generate value is also low. Investors may also have the worst expectations. This is supported by the findings of (Fachrudin \& Ihsan, 2021), namely the probability that financial distress has a negative effect on stock returns.

Based on the elaboration, a hypothesis is proposed that :

H1. Financial distress probability has a significant effect LACVIC

Dylan (1996) in (Fachrudin, 2008)mentions that factors influence company failure, include firm size and growth. The larger the size of a company, the less likely it is to fail. The higher the company's growth, the greater the chance of survival. Company's growth need large funding but it can increase profitability. If the company use much debt, the financial distress probability will be increase. If it is success, the financial distress probability will be decrease. For this reason, the following hypothesis is proposed:

H2. Growth has a significant effect on financial distress probability

In valuation theory, growth of free cash flow is positively related to fair value assets, so it is assumed that it is also positively related to firm value or LACVIC. Aggarwal \& Padhan (2017) examined the effect of firm quality, size, tangibility, profitability, growth and other variables on firm values in the hospitality sector of companies listed on the Bombay Stock Exchange. Firm quality in that study was risk of bankruptcy which was calculated through the Altman Z Score. The results show that the smaller the risk of bankruptcy, the higher the firm value. Firm size and growth have a significant positive effect on firm value, but profitability has a negative and significant effect on Price to Book Value Ratio. Tangibility has a positive and unsignificant effect on Price to Book Value Ratio.

For this reason, the following hypothesis is proposed:

H3. Growth has direct significant effect to the LACVIC

H4. Growth has indirect significant effect to LACVIC through financial distress probability.

Profitability is ability to earn profit. The profit can be distributed to the stockholders and can be held as retained earnings. It can reduce the financial distress probability, but if the company have negative earning, the financial distress probability will increase. Fachrudin (2008) said that profitability is used by Beaver (1966), Gombola et al. (1987), Lo (1986), Ohlson (1980), Theodossiou et al. (1996), and Altman (1968) to predict financial distress. 
HOLISTICA Vol 12, Issue 3, 2021, pp. 101-114

Pecking order theory says that firms with high profitability in the long run will use their own capital so that the use of debt will decrease. This will cause the debt burden to decrease. Based on this hypothesis is proposed:

H5. Profitability has a significant effect on financial distress probability.

Profitability as a proxy of financial performance has significant effect on Price to Book Value in Banking Companies in Indonesia (Siregar, Sadalia, \& Fachrudin, 2018). The higher profitability the greater investor's expectation to earn return. The hypothesis proposed is :

H6. Profitability has direct significant effect to the LACVIC

H7. Profitability has indirect significant effect to the LACVIC through financial distress probability.

Tangible assets as land, buildings, machines, and inventory (E. Brigham \& Ehrhardt, 2017) commonly used by companies as collateral for debts. In this study tangible assets are restricted to only fixed assets according to (Çekrezi, 2013). Cekrezi using the ratio of fixed assets to total assets as a proxy for tangibility According to trade off theory, the tangible assets lowers expected distress cost. But according to (E. Brigham \& Ehrhardt, 2017), companies that have many tangible assets tend to use large debts so that they might be able to increase financial distress probability. To see how the influence of tangibility on financial distress probability in manufacturing companies in Indonesia, the hypothesis is proposed as follows:

H8. Tangibility has a significant effect on financial distress probability.

Free cash flow to firm has a positive and significant effect on the probability in increasing price above average (Fachrudin, 2018). The large proportion of tangible assets will reduce free cash flow because the available funds are used to purchase these assets and their maintenance. Free cash flow is positively related to firm value. Based on this, it is assumed that tangibility assets are negatively related to firm value and LACVIC. But, assets are a pride for companies which may increase company value. Based on that, the hypothesis is proposed as follows:

H9. Assets tangibility has direct significant effect to LACVIC

H10. Assets tangibility has indirect significant effect to LACVIC through financial distress probability.

Firm size is often proxied by total assets which are logarithmically naturalized. Total assets consist of liabilities and equity. Ohlson (1980) in (Fachrudin, 2008) found that the bigger the firm size the smaller the chance of going bankrupt.

Storey (1994) in (Fachrudin, 2008) said there are several factors that affect failure, including firm size and growth. The bigger the company, the less likely it is to fail. Companies with growth are more likely to survive. 
Based on this hypothesis is proposed:

H11. Firm size has a significant effect on financial distress probability.

As Aggarwal \& Padhan (2017) found that the firm size is positively and significantly related to the firm value, the hypothesis proposed is :

H12. Firm size has direct significant effect to LACVIC

H13. Firm size has indirect significant effect on LACVIC through financial distress probability.

This study examines the effect of growth, profitability, size, and tangibility on LACVIC with financial distress probability as an intervening variable. The aim is to determine the factors that can increase firm value. Financial distress probability is used as an intervening variable so that it can be seen whether the company's health level plays a role in increasing LACVIC or not. This research will contribute to the development of knowledge, especially about factors that influence the LACVIC. Another contribution is role of financial distress probability as an intervening variable.

The research conceptual framework is as follows:

Figure 1. Conceptual Framework

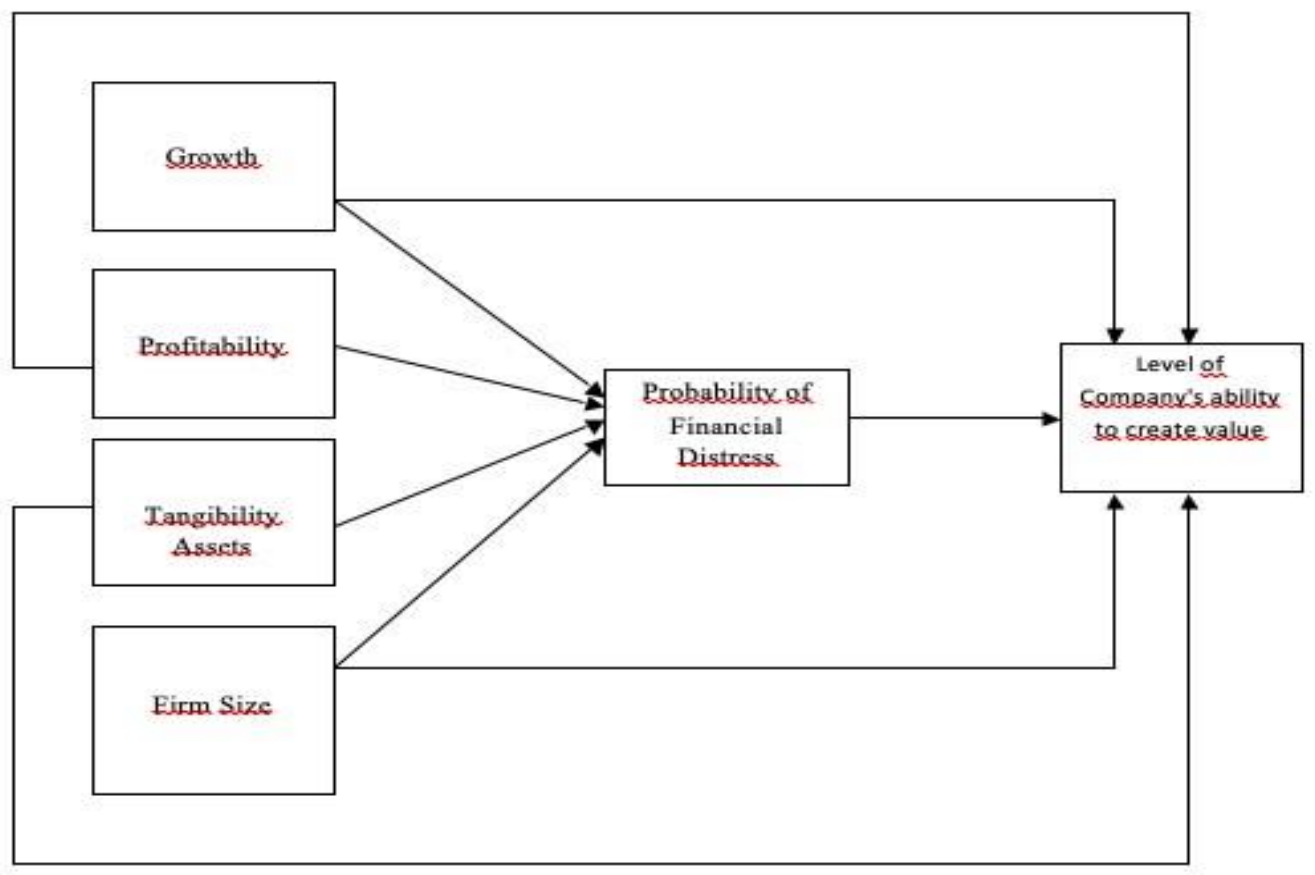

Source : Author's synthesis 


\section{Research Method}

Public manufacturing companies in Indonesia are the population in this study, namely 55 companies. Observations were made on the company's financial statements for the period 2013-2017. The target population is manufacturing companies that do not have negative equity values, so there are 50 companies. All companies in the target population were sampled in this study. Thus the financial data observed are pooled data of 50 companies $x 5$ years $=250$ data. Data analysis is done with path analysis. Data processing is done by Partial Least Squre application program.

This study uses four predictors that explain the effect on the financial distress probability and LACVIC. The financial distress probability in the model is proposed as a mediating variable between predictor variables on LACVIC The research variables are as follows:

Formula of the or $\operatorname{PBV}\left(\mathrm{Y}_{2}\right)$ is :

PBVit $=\frac{\text { Price per Share it }}{\text { Book Value per Share it }}$

Whereas book value per share is common equity divided by shares outstanding. Common equity is common stock plus retained earnings.

The financial distress probability $\left(\mathrm{Y}_{1}\right)$ formula is:

$P_{\text {it }}=1 /\left[1+2,71828^{-(-5,472+9,555 \times 1 i t-32,347 \times 2 \text { it })}\right]$

$\mathrm{X}_{1}=$ the ratio of total liabilities to total assets

$\mathrm{X}_{2}=$ the ratio of net income to total assets

2,71828 denotes e or the natural logarithm

Formula of size $\left(X_{1}\right)$ is :

Growth $_{i t}=\frac{\text { Total Assets it }- \text { Total Assets } \mathrm{i}(\mathrm{t}-1)}{\text { Total Assets } \mathrm{i}(\mathrm{t}-1)}$

Formula of profitability $\left(\mathrm{X}_{2}\right)$ is :

Net Income it $=\frac{\text { Return } \text { on } \text { Assets it }}{\text { Total Assets it }}$

Formula of size $\left(X_{3}\right)$ is :

Size $=\operatorname{Ln}\left(\right.$ Total Assets $\left.{ }_{\text {it }}\right)$ 
Formula of tangibility $\left(\mathrm{X}_{4}\right)$ is :

Tangibility Assets it $=\frac{\text { Fixed } \text { Assets it }}{\text { Total Assets it }}$

Figure 2. Research Model

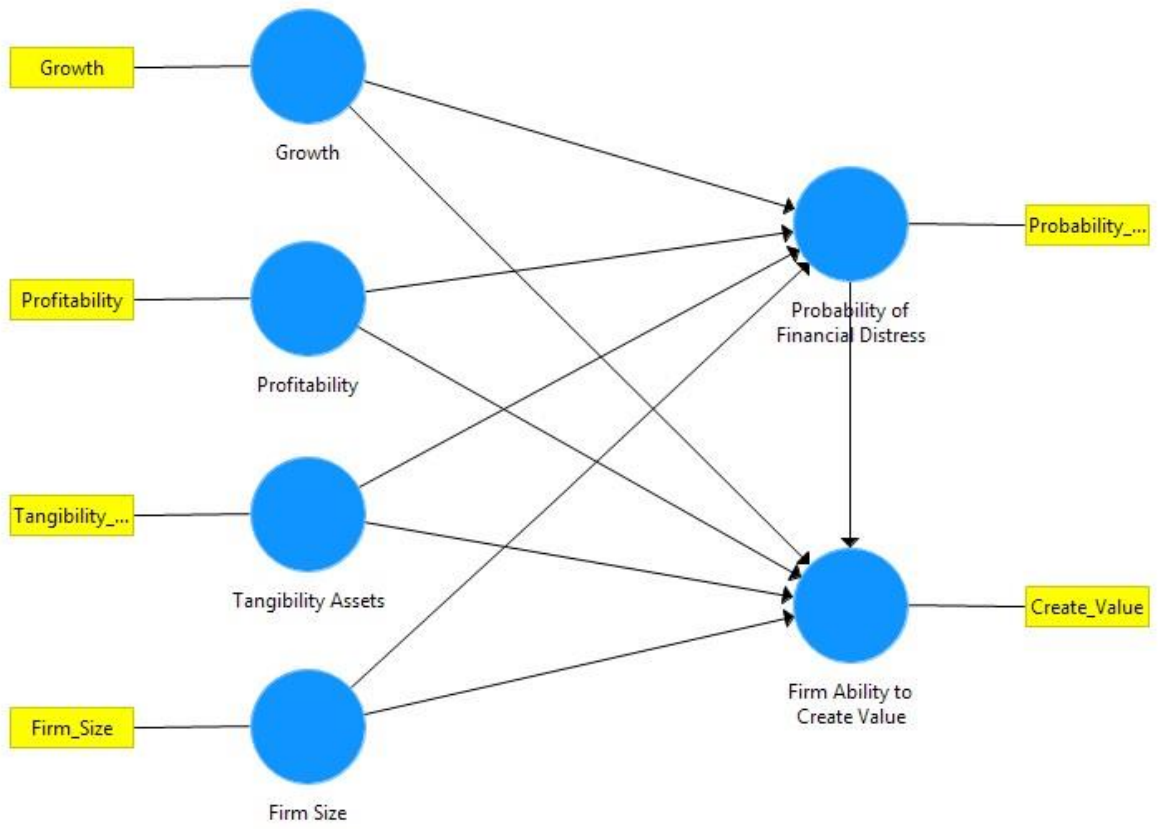

Source: Author's synthesis

\section{Measurement Model}

The structural equation in this study is divided into two structural sub-models, i.e. for the financial distress probability and firm ability to create value. The structural submodel can be written as follows:

$Y_{1}=\gamma_{1} X_{1}+\nu_{2} X_{2}+\gamma_{3} X_{3}+\gamma_{4} X_{4}+\zeta_{1}$

and,

$Y_{2}=\gamma_{5} X_{1}+\gamma_{6} X_{2}+\gamma_{7} X_{3}+\gamma_{8} X_{4}+\gamma_{9} Y_{1}+\zeta_{1}$

Where

$\begin{array}{ll}\mathrm{Y}_{2} & =\text { LACVIC } \\ \mathrm{Y}_{1} & =\text { Financial Distress Probability } \\ \mathrm{X}_{1} & =\text { Growth }\end{array}$


HOLISTICA Vol 12, Issue 3, 2021, pp. 101-114

\begin{tabular}{|c|c|}
\hline$x_{2}$ & $=$ Profitability \\
\hline$x_{3}$ & $=$ Tangibility Assets \\
\hline$X_{4}$ & = Firm Size \\
\hline Gamma $(\gamma)$ & = Effect of exogenous variables on endogenous \\
\hline
\end{tabular}

\section{Empirical Results}

Model Evaluation

This study uses single-item construct so that the values from the evaluation of AVE, Composite Reliability, and Fornell-Lacker Criterion will be fulfilled. Nevertheless, this model will be evaluated based on the R-Square value, F-Square, HTMT Ratio for discriminant validity, and variable collinearity statistics.

Table 1. Quality Criteria

\begin{tabular}{lcc}
\hline & $\begin{array}{c}\text { Financial } \\
\text { Distress Probability }\end{array}$ & PBV* \\
\hline Financial Distress Probability & & 0.002 \\
Firm Size & 0.001 & 0.042 \\
Growth & 0.000 & 0.001 \\
Profitability & 0.185 & 0.047 \\
Tangibility Assets & 0.110 & 0.042 \\
R-Square & 0.175 & 0.278 \\
\hline
\end{tabular}

*PBV shows the LACVIC

Source: Author processed data

Table 1 indicates that the model in this study is able to explain $17.5 \%$ of the situation at the probability level of financial distress probability, and is able to explain $27.8 \%$ of the situation in the LACVIC. More specifically, the ability of firm size and growth has a very weak influence ( $f$-square $<0.02)$ while assets tangibility variables have a weak influence $(0.02 \leq \mathrm{f}$-square $<0.15)$ and profitability variables have moderate influence $(0.15 \leq \mathrm{f}$-square $<0.35)$ on the financial distress probability (Cohen, 1988; Hair, Ringle, \& Sarstedt, 2011). In predicting the LACVIC, the financial distress probability and growth has a very weak influence. Meanwhile size, profitability, and asset tangibility have a weak influence.

Tabel 2. Heterotrait-Monotrait Ratio (HTMT)

PBV* $\begin{array}{llll}\text { Firm } \\ \text { Size }\end{array} \quad$ Growth $\begin{gathered}\text { Financial } \\ \text { Distress } \\ \text { Probability }\end{gathered}$ Profitability $\begin{gathered}\text { Tangibility } \\ \text { Assets }\end{gathered}$


PBV*

Firm Size $\quad 0.210$

Growth $\quad 0.012 \quad 0.055$

$\begin{array}{llll}\text { Financial } & 0.238 & 0.057 & 0.032\end{array}$

Distress

Probability

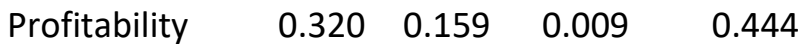

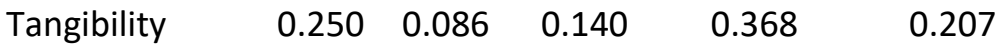

Assets

*PBV shows the LACVIC

Source: Author processed data

The value of the HTMT ratio smaller than 1 indicates that discriminant validity from the model in this study has been fulfilled. The lower the HTMT ratio, the stronger the validity of the model.

Tabel 3. Inner VIF Value Model

Financial Distress

PBV*

Probability

Financial Distress

1.384

Probability

Firm Size

1.047

1.048

Growth

1.026

1.026

Profitability

1.082

1.281

Tangibility Assets

1.085

1.204

*PBV shows the LACVIC

Source: Author processed data

The level of colinearity permitted in the analysis was VIF value $<5$ (Hair et al., 2011). The table above indicates that there is no multicollinearity between predictor variables in the proposed model. Thus, this research model can be continued to analyze the influence between variables. 
HOLISTICA Vol 12, Issue 3, 2021, pp. 101-114

Tabel 4. Direct Effect, Indirect Effect, and Total Effect

\begin{tabular}{|c|c|c|c|c|c|c|c|c|c|}
\hline & \multicolumn{4}{|c|}{ Direct Effect } & \multicolumn{3}{|c|}{ Indirect Effect } & \multicolumn{2}{|c|}{ Total Effect } \\
\hline & $\begin{array}{l}\text { Coeffi } \\
\text { cient }\end{array}$ & $\begin{array}{l}\mathrm{t} \\
\text { Statisti } \\
\mathrm{cs}\end{array}$ & $\begin{array}{l}\mathrm{P} \\
\text { Values }\end{array}$ & $\begin{array}{l}\text { Coeffi } \\
\text { cient }\end{array}$ & $\begin{array}{l}\mathrm{t} \\
\text { Statisti } \\
\mathrm{cs}\end{array}$ & $\begin{array}{l}\text { P } \\
\text { Valu } \\
\text { es }\end{array}$ & $\begin{array}{l}\text { Coeffi } \\
\text { cient }\end{array}$ & $\begin{array}{l}\mathrm{t} \\
\text { Statisti } \\
\mathrm{cs}\end{array}$ & $\begin{array}{l}\text { P } \\
\text { Valu } \\
\text { es }\end{array}$ \\
\hline Firm Size & 0.190 & 3.890 & 0.000 & 0.001 & 0.315 & 0.376 & 0.191 & 3.901 & 0.000 \\
\hline $\begin{array}{l}\text { Firm Size -> } \\
\text { Financial Distress } \\
\text { Probability } \\
\end{array}$ & -0.022 & 0.483 & 0.315 & & & & $\begin{array}{c}- \\
0.022\end{array}$ & 0.483 & 0.315 \\
\hline rowth -> PBV* & -0.030 & 0.870 & 0.192 & $\begin{array}{c}- \\
0.001 \\
\end{array}$ & 0.139 & 0.445 & $\begin{array}{c}- \\
0.031 \\
\end{array}$ & 0.969 & 0.166 \\
\hline $\begin{array}{l}\text { Growth -> Financial } \\
\text { Distress Probability }\end{array}$ & 0.014 & 0.237 & 0.406 & & & & 0.014 & 0.237 & 0.406 \\
\hline $\begin{array}{l}\text { Profitability -> } \\
\text { PBV* }\end{array}$ & 0.224 & 2.562 & 0.005 & 0.020 & 0.722 & 0.235 & 0.244 & 3.171 & 0.001 \\
\hline $\begin{array}{l}\text { Profitability -> } \\
\text { Financial Distress } \\
\text { Probability }\end{array}$ & -0.380 & 6.478 & 0.000 & & & & $\begin{array}{c}- \\
0.380\end{array}$ & 6.478 & 0.000 \\
\hline $\begin{array}{l}\text { Tangibility Assets - } \\
\text { > PBV* }\end{array}$ & -0.204 & 4.440 & 0.000 & $\begin{array}{c}- \\
0.016 \\
\end{array}$ & 0.867 & 0.193 & $\begin{array}{c}- \\
0.220\end{array}$ & 4.499 & 0.000 \\
\hline $\begin{array}{l}\text { Tangibility Assets - } \\
\text { > Financial Distress } \\
\text { Probability }\end{array}$ & 0.293 & 4.075 & 0.000 & & & & 0.293 & 4.075 & 0.000 \\
\hline $\begin{array}{l}\text { Financial Distress } \\
\text { Probability }>\text { PBV* }\end{array}$ & -0.053 & 0.811 & 0.209 & & & & $\begin{array}{c}- \\
0.053\end{array}$ & 0.811 & 0.209 \\
\hline
\end{tabular}

*PBV shows the LACVIC

Source: Author processed data

At $5 \%$ alpha, results are :

1. Financial distress probability has a negative and unsignificant effect on the LACVIC

2. Growth has a positive and unsignificant effect on financial distress probability.

3. Growth has a negative and unsignificant direct effect on the LACVIC

4. Growth has a negative and unsignificant effect on the LACVIC through financial distress probability.

5. Profitability has a negative and significant effect on financial distress probability.

6. Profitability has a positive and significant direct effect on the LACVIC 
HOLISTICA Vol 12, Issue 3, 2021, pp. 101-114

7. Profitability has a positive and unsignificant effect on the LACVIC through financial distress probability.

8. Firm size has a negative and unsignificant effect on financial distress probability.

9. Firm size has positive and significant direct effect on the LACVIC

10. Firm size has a positive and unsignificant effect on the level LACVIC through financial distress probability

11. Assets tangibility has a positive and significant effect on financial distress probability.

12. Assets tangibility has negative and significant direct effect on the LACVIC

13. Assets tangibility has a negative and unsignificant effect on the LACVIC through financial distress probability

Figure 3. Final Model

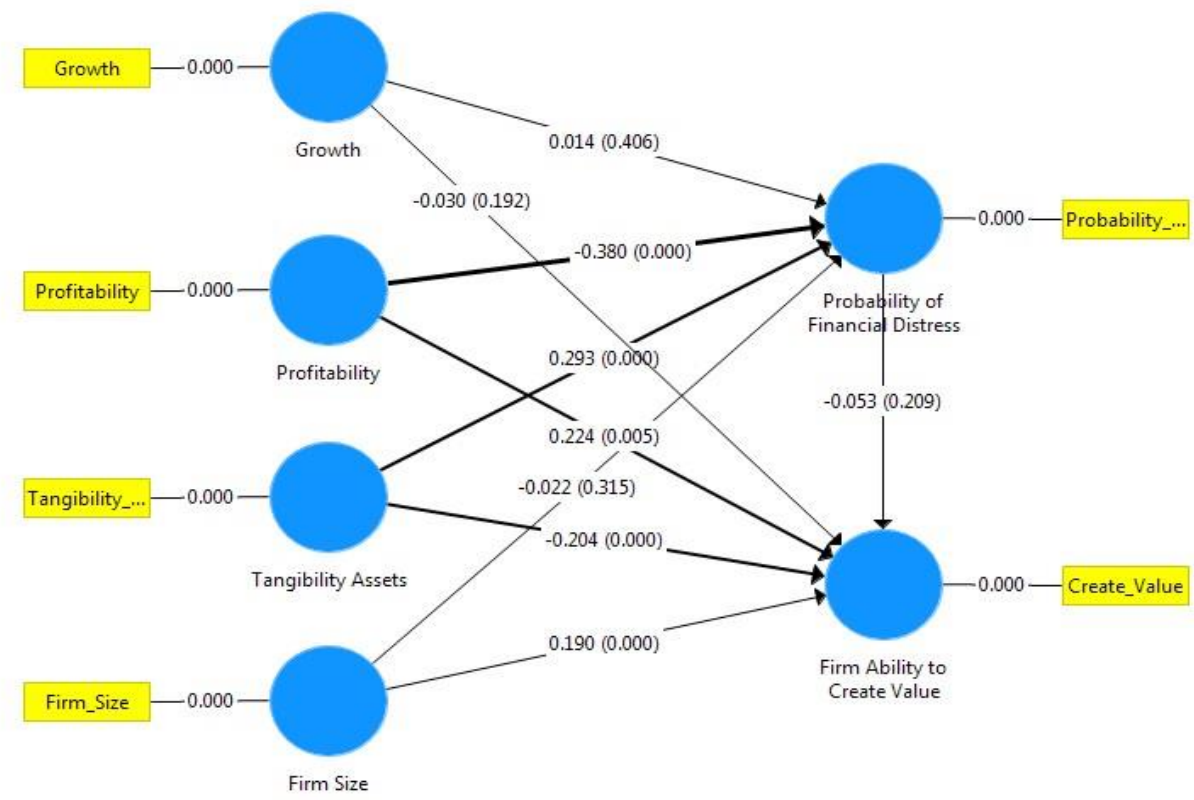

Source: Author processed data

The results show that at alpha 5\%, firm size and growth have unsignificant effect on financial distress probability. Profitability have negative and significant effect on probability of financial distress, but tangibility have positive and significant effect.

Financial distress probability has a negative and unsignificant effect on the LACVIC.

Firm size can directly increase the LACVIC significantly, but it does not significantly increase the value of the company through the probability of financial distress. Growth 
HOLISTICA Vol 12, Issue 3, 2021, pp. 101-114

has unsignificant effect on the LACVIC, either directly or indirectly. Profitability which is proxied by return on assets (Muslim, 2020) has a positive and significant effect on the LACVIC, but it does not significantly increase the LACVIC through the probability of financial distress. From the coefficients and the significance level of the results of the research, it can be seen that the effect of profitability on probability of financial distres is bigger and stronger than its effect on value creation. Tangibility has a negative and significant effect on the LACVIC, but it does not significantly increase the LACVIC through the probability of financial distress.

\section{Discussion}

Growth has no significant effect on the financial distress probability and the LACVIC. In this case the growth of assets does not improve the health of the company and its value. The company should not invest in large amounts of fixed assets. This finding is not in line with (Baker \& Wurgler, 2002) which says that investors tend to appreciate companies that have high growth.

High profitability shows a healthy company so that the probability of financial distress is lower and LACVIC is higher than companies with low profitability. This finding is in line with (Jensen \& Meckling, 1976) which says that an increase in the company's financial performance will increase the LACVIC to provide economic benefits to their shareholders.

Firm size has a negative influence and unsignificant on financial distress probability, but has a positive and significant effect on firm value. These results indicate that there are companies whose assets are productive but some are financing their assets with debt which causes a large interest burden and the health of the company gets worse. This finding is different from the finding of (Levy, 2021) which says that small companies generally experience financial distress

The findings regarding assets tangibility indicate that these assets are used as collateral for debt, thereby increasing financial distress probability and reducing the value of the companies. The findings regarding assets tangibility indicate that these assets are used as collateral for debt, thereby increasing financial distress probability and reducing the value of the companies. This finding is in line with (Xuezhou, Hussain, Hussain, \& Saad, 2020), but not in line with (Daskalakis \& Psillaki, 2008) who found that companies that invest more in tangible assets have lower financial distress costs

\section{Conclusions}

Manufacturing companies that have high profitability will have a good level of financial health, but the more fixed assets will reduce their level of health. Fixed assets cause a burden on companies, such as maintenance expenses and depreciation expenses. Fixed assets cannot immediately generate income, while more liquid assets can immediately generate income. 
HOLISTICA Vol 12, Issue 3, 2021, pp. 101-114

The probability of financial distress that shows the level of company's health does not increase the LACVIC. Companies that have large sizes also have the ability to create high value.

\section{Suggestion}

The company should always manage the health level of the company by increasing profitability. Companies do not need to invest heavily in assets, some assets can be overcome with non-asset solutions such as renting and outsourcing.

The company should not has more fixed assets if it is funded by debt and that fixed assets as collaterals because it will only increase financial distress probability. Companies need to improve their performance to improve their health and increase the LACVIC.

The company should focus on increasing profits because it decreases the probability of financial distress and increases firm value. Company managers should focus on profitability in order to increase the firm's ability to create value. Today, asset requirements do not have to be carried out by owning assets, namely by 'non asset solutions' such as renting assets, selling online, and outsourcing.

The implication for public administration is that an organization does not always have to increase their assets tangibility, the need to provide services can be done in other ways, for example renting, repairing, or outsourcing.

\section{References}

Aggarwal, D., \& Padhan, P. C. (2017). Impact of Capital Structure on Firm Value: Evidence from Indian Hospitality Industry. Theoretical Economics Letters, 07(04). doi: 10.4236/tel.2017.74067

Baker, M., \& Wurgler, J. (2002). Market timing and capital structure. Journal of Finance, 57(1). doi: 10.1111/1540-6261.00414

Brigham, E., \& Ehrhardt, M. (2017). Financial Management - Theory and Practice, 15e. Cengage Learning.

Brigham, E. F., \& Daves, P. R. (2013). Intermediate Financial Management (Ninth Edition). South Western Cengage Learning.

Çekrezi, A. (2013). Impact Of Firm Specific Factors On Capital Structure Decision: An Empirical Study Of Albanian Firms. European Journal of Sustainable Development, 2(4). doi: 10.14207/ejsd.2013.v2n4p135

Chen, M. C., Cheng, S. J., \& Hwang, Y. (2005). An empirical investigation of the relationship between intellectual capital and firms' market value and financial performance. Journal of Intellectual Capital, 6(2). doi: 10.1108/14691930510592771

Cohen, J. (1988). Statistical power analysis for the behavioural sciences. Hillside. NJ: Lawrence Earlbaum Associates.

Daskalakis, N., \& Psillaki, M. (2008). Do country of frm explain capital structure? Evidence from SMEs in France and Greece. Applied Financial Economics, 18, 87-87.

Fachrudin, K. A. (2008). Corporate and Personal Financial Distress. Medan: USU Press. 
HOLISTICA Vol 12, Issue 3, 2021, pp. 101-114

Fachrudin, K. A. (2011). Analysis of the Effect of Capital Structure, Company Size, and Agency Cost on Company Performance . Jurnal Akuntansi Keuangan, 13(1), 37-46.

Fachrudin, K. A. (2018). Stock price analysis of sustainable foreign investment companies in Indonesia. IOP Conf. Series: Earth and Environmental Science $126,1-6$.

Fachrudin, K. A., \& Ihsan, M. F. (2021). The effect of financial distress probability, firm size and liquidity on stock return of energy users companies in Indonesia. International Journal of Energy Economics and Policy, 11(3). doi: 10.32479/ijeep.10677

Hair, J. F., Ringle, C. M., \& Sarstedt, M. (2011). PLS-SEM: Indeed a silver bullet. Journal of Marketing Theory and Practice, 19(2). doi: 10.2753/MTP1069-6679190202

Jensen, M. C., \& Meckling, W. H. (1976). Theory of the firm: Managerial behavior, agency costs and ownership structure. Journal of Financial Economics, 3(4). doi: 10.1016/0304405X(76)90026-X

Levy, D. L. (2021). COVID-19 and Global Governance. Journal of Management Studies, 58(2). doi: $10.1111 /$ joms.12654

Muslim, A. I. (2020). The Effect of Firm Value and Financial Performance on Eranings Management in Sharia Issuers : Evidence from the Indonesia Stock Exchange. JBFEM, 3(1). doi: 10.32770/jbfem.vol313-22

Purwohandoko. (2017). The Influence of Firm's Size, growth, and Profitability on firm value with capital structure as the mediator : a study on the agricultural firms listed in the Indonesian Stock Exchange. International Journal of Economics and Finance, 9(8), 103-110.

Siregar, D., Sadalia, I., \& Fachrudin, K. A. (2018). The Influence of Intellectual Capital and Capital Structure on Company Value with Financial Performane as Intervening Variable in Go-Public Banking on Indonesia Stock Exchange . International Journal for Innovative Research in Multidisciplinary Field. , 4(8), 39-49.

Xuezhou, W., Hussain, R. Y., Hussain, H., \& Saad, M. (2020). Interaction of Asset Tangibility on the Relationship between Leverage Structure and Financial Distress in Agriculture - Linked Non-Financial Firms. Scientific Papers Series Management, Economic Engineering in Agriculture and Rural Development, 20(3). 